\title{
A SIMPLE STORY O LA DELICADA FRONTERA ENTRE LO PERMITIDO Y LO PROHIBIDO
}

\author{
AIIDA DÍAZ BILD \\ Universidad de La Laguna
}

\section{RESUMEN}

Según la mayoría de los críticos, A Simple Story, de Elizabeth Inchbald, es una novela subversiva y Miss Milner una mujer que rehúsa ser confinada dentro de las barreras de lo "femenino" en el orden patriarcal, que se resiste a los ideales de la dócil mujer doméstica descrita en los libros y novelas de conducta de la época. En este sentido la historia de Miss Milner es de trastorno, de ley y su violación. En este artículo analizo hasta qué punto Inchbald desafía tanto al decoro literario como al doméstico y hasta qué punto Miss Milner no consigue cumplir con el ideal femenino convencional. Mi argumento principal es que Miss Milner no es un personaje tan agresivo como la mayoría de los críticos lo han descrito, sino una figura de compromiso, cuyo comportamiento se constituye según los aspectos más fundamentales del gusto de la audiencia y sus preferencias ideológicas.

Palabras clave: lo "femenino", novelas de conducta, decoro literario y decoro doméstico.

\begin{abstract}
According to most critics A Simple Story, by Elizabeth Inchbald, is a subversive novel and Miss Milner a woman who refuses to be confined within the boundaries of the "feminine" in the patriarchal order, who resists the ideals of the docile, domestic woman as described in the conduct books and novels of the age. In this sense Miss Milner's story is one of disruption, of law and its violation. In this article I analyse to what extent Inchbald challenges literary as well as domestic decorum and to what extent Miss Milner fails to meet the conventional feminine ideal. My main argument is that Miss Milner is not such a transgressive character as most critics have claimed, but a figure of compromise, whose behaviour conforms in the most fundamental aspects to the audience's taste and ideological preferences.
\end{abstract}

Key words: the "feminine", conduct novels, literary decorum and domestic decorum. 
En los últimos años la crítica feminista ha intentado recuperar los textos de escritoras del siglo XVIII que habían quedado sumidos en el olvido y así establecer lazos de continuidad entre la literatura femenina del siglo XVIII y la del XIX. Una de las escritoras que más interés ha despertado es, indudablemente, Elizabeth Inchbald, actriz, dramaturga, novelista, traductora y clara simpatizante de los denominados autores jacobinos. La crítica ha detectado la presencia de claras concomitancias entre A Simple Story (1791) y Wuthering Heights en el empleo de una estructura narrativa doble ${ }^{1}$ y el modo en que ambas proyectan "reserves of the most intense feeling" (Castle, 1986: 291) y ha subrayado los paralelismos existentes entre la obra de Inchbald y Jane Austen. Mientras que Castle considera que Inchbald "shares the profound interiority of Jane Austen and Henry James" (291), Jane Spencer y Bradbrook consideran que el estilo irónico de Inchbald anticipa el que luego desarrollará Austen en sus novelas. Bradbrook también ha establecido semejanzas entre algunos personajes de Jane Austen e Inchbald y ha afirmado que ambas escritoras comparten ciertos temas y preocupaciones.

Pero el aspecto que la crítica contemporánea más ha destacado de la producción novelística de Inchbald, que incluye A Simple Story y Nature and Art (1795), es el talante subversivo de la misma ${ }^{2}$, es decir, el modo en que la escritora transgrede los límites de la novela sentimental para convertir el género en un documento de afirmación femenina. El principal objetivo de este trabajo es, precisamente, revisar las diversas lecturas que hasta el momento se han hecho de A Simple Story con el fin de cuestionar este talante disruptivo que se le ha otorgado a A Simple Story y, más concretamente, a su heroína, Miss Milner.

Un trabajo clave es, sin lugar a dudas, "Masquerade and Utopia II: Inchbald's 'A Simple Story",, de Terry Castle, que se incluye en su libro Masquerade and Civilization (1986). De hecho, es raro el artículo o libro publicado posteriormente sobre la obra de Inchbald que no haga a referencia a Castle, ya sea para indicar la discrepancia o conformidad con sus ideas. El fin primordial de Castle es rescatar A Simple Story del lugar secundario que la crítica siempre le ha otorgado y demostrar su importancia dentro de la producción literaria del siglo XVIII. De ahí que no dude en afirmar que A Simple Story es "a tour de force -a small masterpiece neglected for too long. Without exaggeration the case might be made for A Simple Story as the most elegant English fiction of the century" (290). Para Castle A Simple Story es el primer romance feminista, una obra vanguardista y antiautoritaria en la que los deseos de la heroína triunfan repetidamente sobre las prerrogativas masculinas y en la que todas las estructuras familiares, religiosas y psíquicas de dominación masculina se derrumban ante su persistente búsqueda de libertad. La novela es "a rhapsody of transgression" (293), en la que la autoridad masculina se desmitifica continuamente y las aspiraciones femeninas son recompensadas. A lo largo de la obra se viola la ley y se cruzan fronteras prohibidas, sin que ello tenga repercusiones nefastas para la heroína:

\footnotetext{
${ }^{1}$ Doody y Ty también han sugerido que hay ciertas afinidades entre The Memoirs of Miss Sidney Bidulph (1761), de Frances Sheridan, y A Simple Story, ya que la primera cuenta la historia de tres generaciones de mujeres, mientras que la segunda se centra en dos generaciones.

${ }^{2}$ Para la mayor parte de la crítica este carácter irreverente de la obra de Inchbald está claramente vinculado a su relación con los denominados autores jacobinos, de claras ideas liberales y revolucionarias. Gary Kelly ha destacado en The English Jacobin Novel, 1780-1805, el papel fundamental que Inchbald desempeñó en el desarrollo de la novela jacobina a finales del siglo XVIII.
} 
"The result is utopian - a physical order without negativity, a realm of ideal freedom" (295). En la primera parte de la novela la heroína, Miss Milner, transgrede todos los tabús existentes. Es una chica frívola que se enamora de su tutor, un sacerdote jesuita, enfrentándose así a las leyes de la Iglesia Católica y violando algo tan sagrado como es la relación entre tutor y pupila. Cuando todos los impedimentos para su relación desaparecen al tener que renunciar Dorriforth a sus votos para poder heredar un título nobiliario y convertirse en el nuevo Lord Elmwood, Miss Milner no contenta con tener el cariño y la pasión de su amado, decide poner a prueba la paciencia de éste y desafiar su autoridad. El momento culminante se produce cuando Lord Elmwood le prohíbe ir a un baile de máscaras y la heroína desobedece su orden. Miss Milner prefiere reafirmar su autonomía personal y su independencia asistiendo a la fiesta, aunque sabe que ello puede costarle la felicidad con Lord Elmwood, como así sucede. Sin embargo, al final y de una forma un tanto "milagrosa" se produce la unión de los dos enamorados, y aunque en este sentido la novela parece acabar como la mayoría de los textos de la época, Castle considera que Inchbald introduce una diferencia importante al no obligar en ningún momento a Miss Milner a pedir perdón por lo que ha hecho o prometerle a su futuro marido total sumisión: "The masquerade, finally, is both the token of utopian aspirations and the lyrical mechanism through which Inchbald grants her heroine everything - the double euphoria of carnival, love and power, in the shape of the everyday" (320).

Ty, para quien la novela muestra evidentes concomitancias con los textos de escritoras feministas de la década de los noventa, como Wollstonecraft o Hays, coincide con Castle en resaltar el carácter subversivo de la primera parte de A Simple Story. ${ }^{3}$ Partiendo de la teoría psicolingüística de Lacan y las tesis feministas psicosociales de Chodorow, Ty afirma que la historia de Miss Milner es ante todo la de una joven que se niega a formar parte del orden simbólico. Miss Milner es un personaje subversivo que rechaza el ideal de la mujer sumisa y dócil imperante en la época. No sólo viola todos los códigos sociales, religiosos y culturales al enamorarse de su tutor, un sacerdote católico, sino que desea tener el poder de elegir: "In Kristeva's terms Miss Milner could be said to represent the semiotic pulsions which are constantly erupting and disrupting the orderly symbolic structure" (88). Miss Milner prefiere recurrir al lenguaje semiótico preverbal de gestos, miradas, exclamaciones, etc. ya que desconfía de la capacidad del lenguaje como medio de expresión ${ }^{4}$. La gran victoria de Miss Milner se produce precisamente cuando, a pesar de

\footnotetext{
${ }^{3}$ Es en la valoración que Castle hace de la segunda parte de A Simple Story donde encontramos la principal fuente de fricción entre este y otros críticos. Mientras que la mayoría de los estudiosos han destacado el carácter conservador y un tanto pesimista de la segunda parte, Castle ha defendido no sólo que Matilda es la perfecta sustituta de Miss Milner, sino que la estructura narrativa de la segunda parte es idéntica a la de la primera, repitiéndose el mismo patrón de prohibición/violación/recompensa.

${ }^{4}$ En "Women and the Rise of the Novel: Sexual Prescripts" Ros Ballaster explica cómo en la novela de sensibilidad escrita a finales del siglo XVIII, principios del XIX, el cuerpo femenino se convierte en un texto que ha de ser interpretado por los hombres y niños y que, curiosamente, la fuente original de sensibilidad suele ser la figura de la madre. Ballaster cita como ejemplo el caso de Matilda, que ha de cumplir la orden de su padre de evitar aparecer en su presencia para así no recordarle a su "faithless and sensibility-suffused mother" (211). En A Simple Story la sensibilidad se convierte en la única respuesta válida a una autoridad patriarcal opresora. Miss Milner ha de recurrir a su cuerpo para poder expresar lo que no puede decir con palabras.
} 
su constante violación de la ley del padre, consigue convertirse en la mujer de Lord Elmwood. Pero un personaje que representa la transgresión y se niega a entrar en el orden simbólico no puede quedar impune y al final Miss Milner termina pagando por ello con su muerte.

Para Spacks A Simple Story es, ante todo, una novela que demuestra lo difícil que es armonizar la razón y la emoción, el poder "masculino" y la comprensión "femenina" y alcanzar así lo que Spacks denomina "energy of mind". Spacks no niega que la primera parte de la novela nos ofrezca imágenes recurrentes de libertad y poder femeninos. Nos encontramos con una heroína que intenta satisfacer sus deseos, que manipula a sus admiradores y que una vez que Dorriforth ha reconocido su amor por ella, pone a prueba su poder sobre él. Pero con el comienzo de la segunda parte toda esa imagen de libertad se desvanece. El lector se da cuenta de que es imposible conseguir, no sólo en el caso de Lord y Lady Elmwood, sino en general, el ideal de "energy of mind", es decir la fusión de pensamiento y sentimiento, y de que con el comienzo de la historia de Matilda se produce una reafirmación del orden social tradicional. Miss Milner, tras cometer adulterio, acepta el poder absoluto de su marido y Matilda a su vez asume la autoridad de su padre sobre ella.

Para Jane Spencer A Simple Story es una de las novelas más extraordinarias de finales del siglo XVIII y coincide plenamente con las autoras hasta ahora mencionadas en que el tema principal de la novela no es la educación, puesto que ésta funciona de forma negativa en la obra imponiendo tabús y restricciones, en especial sobre el deseo femenino. Inchbald vincula el deseo de la heroína hacia Dorriforth con su lucha por mantener el poder sobre él $\mathrm{y}$, de este modo, poner de manifiesto la capacidad subversiva del deseo femenino: "Miss Milner embodies the female sexuality that women writers of Inchbald's time were busy denying in the interests of their own respectability, and women's claims for better treatment" (xiv). Spencer enfatiza la extrema delicadeza con que Inchbald trata este tema para no herir la sensibilidad de sus lectores y explica que esta cautela para que el comportamiento transgresor de Miss Milner no resultara inaceptable u ofensivo debió surgir de la críticas que la escritora recibió por el contenido indecente de sus primeras comedias ${ }^{5}$. Asimismo, Spencer coincide con algunos de los estudiosos hasta ahora mencionados en que el destino trágico de Miss Milner era ineludible, ya que las convenciones literarias del momento no permitían un final feliz para un personaje que con su ingenio y sexualidad había amenazado la autoridad de su tutor.

En una línea similar a la de Spencer, Rogers considera que Inchbald se aleja en la primera parte de A Simple Story de los valores de la época al presentarnos a una joven protagonista que no se adapta al ideal femenino imperante y que insiste en hacer su voluntad. A diferencia de las autoras hasta ahora citadas, Rogers cree que a través de Miss Milner y de su carácter frívolo e imprudente, Inchbald está criticando la deficiente educación que las mujeres recibían en el siglo XVIII y señalando cómo a una persona a la que nunca se la ha enseñado a razonar por sí misma, no puede exigírsela que se preocupe por

\footnotetext{
${ }^{5}$ En "Penelope's Daughters" Macheski también ha señalado que Miss Milner sólo llega en su transgresión a los límites que la sociedad le permite. Macheski afirma que Smith, Lennox e Inchbald crean un nuevo tipo de heroína lo suficientemente femenina para enfrentarse a los rígidos parámetros de su audiencia, pero a la vez poseedora de energía, ingenio e independencia.
} 
temas serios o ser consciente de las consecuencias de su acciones. Dorriforth por su parte sólo puede juzgar o valorar el comportamiento de Miss Milner según la ideología de la época y, por supuesto, lo que él espera de una mujer es la sumisión absoluta. Puesto que Dorriforth y Miss Milner son personajes con personalidades tan diferentes es evidente que, a pesar de su profundo amor, su matrimonio no sería nunca un camino de rosas y, en este sentido, Rogers lamenta que Inchbald no haya aprovechado la ocasión para ofrecernos un análisis original y brillante de un matrimonio incompatible: "An honest, sympathetic picture of marital discord, with the faults distributed between the two people as they realistically would be, was outside the range of the novel at the time because it conflicted too sharply with the conventional ideal that a good wife must be submissive, uncritical, and inviolably chaste" (71).

Bradbrook también ha destacado el carácter subversivo de Miss Milner, comparándola con Emma, la heroína de Jane Austen e Isabella, uno de los personajes de The Old Manor House, de Charlotte Smith: "All three heroines reflect changes in ideas on woman's role in society" (110). Las tres son independientes, poseen ingenio e inteligencia y confianza en sí mismas y representan a la "new woman". ${ }^{6}$

Schofield por su parte ha puesto el énfasis en el realismo con que Inchbald describe la situación de la mujer en el siglo XVIII y, más concretamente, en el deseo de la escritora de hacer que sus lectores despierten de su letargo e inocencia y se den cuenta de que están rodeadas de hombres que las manipulan y oprimen: "If nothing else, A Simple Story presents stark realism" (177). En términos de la ideología masculina Miss Milner es un ejemplo de lo que no se debe ser, ya que no sólo se niega a que nadie la controle, sino que además intenta poner a prueba su poder sobre su futuro marido. De ahí que su conducta enérgica y desafiante tenga que ser duramente castigada.

Mi principal objetivo en las páginas que siguen es demostrar que Miss Milner no es un personaje tan subversivo como la mayoría de los críticos han señalado, sino que, al crear este ser de ficción, Inchbald se movió con gran cautela dentro de los patrones de comportamiento sancionados por la época. Inchbald, al igual que otras escritoras decimonónicas, y por razones de índole puramente prácticas, ya que su subsistencia dependía de la aceptación de su obra por parte de los lectores, se adapta en lo esencial al ideal de feminidad imperante en el siglo XVIII. Para entender hasta qué punto Inchbald se ajusta a la construcción ideológica que del sujeto femenino se hace en su centuria es necesario hacer referencia a los manuales de conducta que de forma tan significativa dibujaron el perfil y comportamiento de la mujer perfecta y virtuosa: "In confounding assumptions of 'natural' gender difference with definitions of 'proper' or 'suitable' behaviour, the conduct book sought to conceptualise and interpret female behaviour as predictor of social behaviour more generally" (Sutherland, 2000: 26). Nancy Armstrong, para quien los libros de conducta contribuyeron de forma decisiva al surgimiento de la clase media, ha explicado que estos manuales gozaron de tal popularidad en el siglo XVIII que a mediados de la centuria el ideal de mujer que se describía en sus páginas era conocido y aceptado por prácticamente todo el mundo. De hecho, si el número de manuales publicados disminuye a finales de

\footnotetext{
${ }^{6}$ Linda Hunt coincide con Bradbrook en que existen semejanzas entre las tres heroínas, pero considera que la actitud de estas jóvenes aparece reflejada en las novelas como un defecto más que una virtud. De hecho, el descaro de Miss Milner sólo la lleva a la deshonra y la muerte.
} 
siglo no es porque los lectores hayan perdido interés en los mismos, sino porque "by this time the ideas had passed into the domain of common sense where it provided the frame of reference for other kinds of writing, among them the novel" (63).

Pero, ¿cuáles son las virtudes que debe poseer esta mujer ejemplar que los libros de conducta ensalzan? The Polite Lady: or, a Course of Female Education in a Series of Letters from a Mother to her Daughter (1760) lo resume claramente: templanza, castidad, modestia, compasión y piedad. De hecho, otro de los manuales más leídos, The Ladies Calling, (1673), atribuido a Richard Allestree, nos ofrece la siguiente tabla de contenidos:

\author{
Part I: I Of Modesty \\ II Of Meekness \\ III Of Compassion \\ IV Of Affability (cit. en Brophy, 1991: 7).
}

Una y otra vez se insiste en que el gran tesoro que la mujer posee es su castidad y por ello debe aprender a controlar sus pasiones para así no desviarse de este ideal de pasividad femenina. Wetenhall Wilkes en uno de los textos más famosos de la época, A Letter of Genteel and Moral Advice to a Young Lady (1740), nos ofrece la típica exaltación de la castidad femenina:

Chastity is the next virtue, that is to fall under your consideration; no charm can supply its place; without it beauty is unlovely, wit is mean and wanton; quality contemptible, and goodbreeding worthless. She, who forfeits her chastity, withers by degrees into scorn and contrition; but she, who lives up to its rules, ever flourishes, like a rose in June, with all her virgin graces about her-sweet of the sense, and lovely to the eye. Chastity heightens all the virtues, which it accompanies; and sets off every great talent, that human nature can be possessed of. It is not only an ornament, but also a guard to virtue. This is the great point of female honour, and the least slip in a woman's honour, is never to be recovered. This, more than any other virtue, places your sex in the esteem of ours...

Chastity is a suppression of all irregular desires, voluntary pollutions, sinful concupiscence, and of an immoderate use of all sensual, or carnal pleasures (...) Chastity is so essential and natural to your sex, that every declination from it is a proportionable receding from womanhood. An immodest woman is a kind of monster, distorted from it proper form (cit. en Jones, 1991: 29-30).

Hannah More, una de las mujeres más influyentes de la época también insiste en que "Propriety is to a woman what the great Roman critic says action is to an orator; it is the first, the second, the third requisite. A woman may be knowing, active, witty, and amusing; but without propriety she cannot be amiable" (cit. en Jones, 1991: 131-2)

Para preservar su pureza la mujer ha de evitar las malas compañías y "to deny themselves the most innocent liberties when any scandalous inference is like to be deduced from them" (cit. en Brophy, 1991: 8). En una carta de la época leemos cómo una amiga le recomienda a otra que envíe a su hija a un internado para que así aprenda que su verdadera finalidad en la vida no es la de "to flirt about the world like a butterfly wholly governed by her inclinations, full of herself and fond admirers" (cit. en Brophy, 1991: 47). La frivolidad 
en una joven es altamente peligrosa, ya que supone una seria amenaza para su reputación, el mayor y más frágil tesoro que una mujer posee en el siglo XVIII. Asimismo, un ansia desenfrenada de participar en toda serie de actos públicos y sociales y ser vista por los demás puede destruir el respeto hacia una mujer. John Gregory ratifica esta idea en $A$ Father's Legacy to his Daughters (1774) al afirmar que entre "those virtues and accomplishments which render you most respectable and most amiable in the eyes of my own sex" está "that modest reserve, that retiring delicacy, which avoids the public eye, and is disconcerted even at the gaze of admiration" (cit. en Jones, 1991: 45). Según Gregory y otros autores, la mujer debe en todo momento adoptar una actitud de modestia y humildad y evitar ser atrevida o ingeniosa en sus comentarios. Nancy Armstrong ha explicado con gran claridad el porqué de este rechazo a que las féminas busquen entretenimientos que impliquen la exposición de su persona:

It is a woman's participation in public spectacle that injures her, for as an object of display, she always loses value as a subject. More than that, these books lump the woman of fashion together with "numberless" others who - in the conduct book's terms - similarly lack the quality of subjectivity that makes a woman desirable; she cannot be "seen" and still be vigilant (77).

La principal lección que los libros de conducta impartían a las mujeres era que lo "natural" era que su vida estuviera marcada por el silencio, la negación, la represión y la sumisión. Para endulzar esta dura realidad se les hacía creer que su comportamiento pasivo y virtuoso les daba cierto poder sobre aquellos que las oprimían y vejaban: "Feminine chastity was a kind of power in a situation of considerable powerlessness and most women thought it absurd to throw such influence away" (Todd, 1989: 209).

Por otro lado, es necesario resaltar que la castidad no sólo era una virtud sexual, sino que tras la exaltación que se hacía de la represión sexual femenina latían claros elementos de clase y económicos. Como bien ha explicado Stone, en el siglo XVIII se establece una clara relación en las clases acomodadas entre castidad y poder económico, ya que el hombre y la mujer negocian en el mercado del matrimonio con bienes totalmente distintos: él le ofrece una posición social y económica y ella su pureza sexual: "The system serves the interests of both parties, since the male is guaranteed that he is purchasing new and not second-hand goods, while the female has a powerful lever to obtain marriage" (401). De ahí que en las estratos inferiores, en los que no había problemas de herencia o repartición de bienes, la actitud hacia la castidad fuera más tolerante.

Este énfasis en que la mujer ha de mostrar en todo momento un comportamiento y una moralidad intachables - léase pureza, sumisión, humildad - hace que ésta en un momento dado se convierta en la "refiner" no sólo de su hogar sino también de la sociedad. Mientras que en 1774 John Gregory afirma que las mujeres no son las esclavas del hombre sino sus compañeras, "designed to soften our hearts and polish our manners" (cit. en Jones, 1991: 45), veinte años más tarde James Fordyce va más allá y defiende que las mujeres han de promover una reforma general entre los hombres. En términos semejantes se expresa Thomas Gisborne en An Inquiry into the Duties of the Female Sex (1798) cuando afirma que la mujer puede tener una influencia importante en la sociedad "forming and improving the 
general manners, dispositions and conduct of the other sex, by society and example." (cit. en Hunt, 1986: 17). Esta función regeneradora y redentora de la mujer es especialmente enfatizada a finales del siglo XVIII y principios del XIX. La mujer más que agradar al hombre, tiene que reformarlo y de ella depende la conducta del marido en el hogar.

En un interesante artículo titulado "The cult of womanhood in eighteenth-century thought", Marlene LeGates explica que realmente no hay nada nuevo en esta exaltación de la castidad y obediencia de la mujer, ni en el reconocimiento de su superioridad moral y capacidad redentora. Lo que sí es diferente es la dramatización del tema: "This new literature, centering on the encounter between a sexually aggressive male and the innocent, superior female, was the traditional conduct book fictionalized" (27). Paradójicamente, esta trama en que la virtuosa doncella refrena los impulsos del agresivo caballero no es más que una confirmación de la autoridad patriarcal de la familia, ya que la superioridad moral de la mujer no puede llevarla al individualismo incontrolado, sino que debe estar bajo el poder del hombre. LeGates apunta que este deseo de la Ilustración de encomiar a la mujer como soporte de la moralidad pública y privada es fruto del contexto social e histórico del momento:

The new image of Womanhood was an attempt on the part of the upper classes to consolidate their precariously won prosperity and security against the "outs" of society. But, in keeping with Enlightenment thought, the contribution of woman to humanity and to social exclusivity was a potential only, which needed guidance to be realized (38).

Pero al mismo tiempo que los manuales de la época exaltan la superioridad moral de la mujer, enfatizan que necesitan de la protección, control y dirección del hombre para poder llevar a cabo su labor redentora. La mujer, débil de intelecto "por naturaleza" y propensa a abandonarse a sus pasiones y emociones, debe dejarse guiar y proteger por el hombre, que es el verdadero poseedor de la sabiduría y el raciocinio. The Whole Duty of a Woman lo expresa con claridad: "Our sex wants the other's reason for our conduct and their strength for our protection. Theirs want our gentleness to soften and entertain them" (cit. en Brophy, 1991: 11-12). Esta idea se repite una y otra vez en los principales manuales de la época y contribuye de forma decisiva a perfilar el papel de sumisión que la mujer ha de desempeñar en la sociedad. Otro ejemplo evidente lo encontramos en uno de los textos más célebres, The Lady's New Year's Gift: or, Advice to a Daughter (1688), de George Savile, Marquis of Halifax:

That there is Inequality in the Sexes, and that for the better Oeconomy of the World, the Men, who were to be the Lawgivers, had the larger share of Reason bestow'd upon them; by which means your Sex is the better prepar'd for the Compliance that is necessary for the better performance of those Duties which seem to be most properly assigned to it (cit. en Jones, 1991: 18).

Lo irónico de esta situación es, como bien ha apuntado Brophy, que la sociedad esperara un comportamiento ejemplar y superior al del hombre de unos seres a los que consideraba deficientes en raciocionio e intelecto y proclives a dejarse llevar por sus 
pasiones y caprichos. Esta doble moralidad, que concedía al hombre una mayor libertad de movimiento, especialmente en el ámbito sexual, prevaleció a lo largo del siglo XVIII y fue duramente criticada por algunas mujeres progresistas, conscientes de las contradicciones de ese doble rasero utilizado para medir el comportamiento de hombres y mujeres ${ }^{7}$. Mary Robinson nos proporciona un ilustrativo ejemplo:

How many vices are there that men perpetually indulge in, to which women are rarely addicted. Drinking, in man, is reckoned a proof of good fellowship; and the bon vivant is considered as the best and most desirable of companions. Wine, as far as it is pleasant to the sense of tasting, is as agreeable to woman as to man; but its use to excess will render either brutal. Yet man yields to its influence, because he is the stronger-minded creature; and woman resists its power over the senses, because she is the weaker. How will the superiorly organized sex defend this contradiction? (cit. en Jones: 238).

Pero, a pesar de que algunas voces se alzaron contra la doble moralidad de la época, lo cierto es que se siguió asociando a las mujeres con los sentimientos y las cuestiones más triviales y a los hombres con la razón, el conocimiento y el control, creando así un sistema absolutamente jerárquico y no complementario, como los manuales de conducta querían hacer creer, en el que todo el poder residía en el hombre. Como bien ha explicado Susan Moller Okin, ello contribuyó de forma decisiva a la exclusión de la mujer de cualquier definición de ciudadanía (cit. en Skinner, 2000: 104).

Aunque el objetivo principal de la mujer en el siglo XVIII era encontrar un marido y casarse - el matrimonio era considerado el estado ideal y natural de la mujer - lo cierto es que las normas de conducta exigían que las jóvenes mantuvieran durante el cortejo una actitud de indiferencia e incluso aversión para que no se las considerara víctimas de ardientes pasiones que una muchacha casta y pudorosa no podía albergar. La autora anónima de The Whole Duty of a Woman: Or a Guide to the Female Sex from the Age of Sixteen to Sixty afirma que aquellas mujeres que alientan a sus enamorados "give cause to suspect they are spurred on by somewhat too warm desires"(cit. en Brophy, 1991: 107). Incluso cuando se trata de un noviazgo aceptado por los padres, "as your love kindles...be sure to keep it from blazing outwardly” (cit. en Brophy, 1991: 107). Lady Bradshaigh, apenada por el comportamiento de Olivia en Sir Charles Grandison, comenta: "There is something so monstrous in a woman's coming to court and make love in plain terms (be the man Sir Charles Grandison or an angel) that I can hardly suppose it possible" (cit. en Brophy, 1991: 107). Pero si la mujer ha de ser immune a todo tipo de "warm desires" y no debe ser nunca la que inicie una relación, el hombre tiene total libertad para seguir sus inclinaciones y mostrarle a su amada su incondicional devoción y amor. Este último aspecto es importante porque el noviazgo era el único periodo en la vida de una mujer en el que ésta gozaba de cierto poder e influencia sobre el hombre. Lamentablemente, se trataba de un falso espejismo, porque en cuanto se convertía en la esposa legal de su amado, éste ejercía con total impunidad la autoridad que la sociedad le otorgaba. Mary

\footnotetext{
${ }^{7}$ Es importante señalar que esta doble moralidad se sustentaba sobre una fundamentación práctica, ya que la mujer que cometía adulterio podía dar a luz a un hijo ilegítimo que heredaría una fortuna que no le pertenecía.
} 
Astell y Lady Bradshaigh advierten a las jóvenes que no se dejen deslumbrar por las promesas de sus ardientes enamorados:

She must be a fool who can believe a man, proud and vain as he is, will lay his boasted authority, the dignity and prerogative of his sex, one moment at her feet but in prospect of taking it up again to more advantage. He may call himself her slave a few days, but it is only to make her his all the rest of his life (cit. en Brophy, 1991: 146).

The power you (husbands) give up is no more than a cat allows the poor mouse in its claws, giving it hopes of power yet never out of reach, and ready to assert prerogative upon the first effort it makes towards liberty (cit. en Brophy, 1991: 140).

Evidentemente, el concepto de feminidad predominante en el siglo XVIII influyó de forma decisiva en la producción de las novelistas de la época, que en su deseo de inscribir la novela en un marco de respetabilidad y huir de las acusaciones de inmoralidad de las que las obras de ficción eran objeto por parte de la crítica y los lectores - Fordyce llegó a decir que aquellas mujeres que leían novelas debían "in her soul be a prostitute" (cit. en Jones, 1991: 176) - intentaban respetar las reglas de decoro establecidas, prestando especial atención a las implicaciones morales de sus obras. Si, como se decía, un gran número de jovencitas estaban llenando sus cabezas de absurdas ideas románticas que nada tenían que ver con el mundo real, la única manera de reivindicar el género novelístico y disociarlo de una serie de autoras de segunda fila que presuntamente estaban causando un gran daño moral a las lectoras, era escribiendo historias a través de las cuales se reafirmaran los valores y actitudes aceptadas por la sociedad. De ahí que en la novela que se escribe a partir de la segunda mitad del siglo XVIII se enfatice la obediencia, el sentido común y el decoro como virtudes deseadas en las mujeres. Asimismo, se promueve una especie de "moralidad prudencial", que defiende que la obediencia filial está por encima de los propios deseos, que la castidad es un privilegio más que un deber, que las mujeres deben ser sumisas con sus maridos y que la delicadeza y la sensibilidad son aspectos que hay que cultivar. El hecho de que estas mujeres escritoras apoyen, al menos aparentemente, la ideología de la época genera una contradicción que Turner ha explicado con gran perspicacia: 'In other words, something as seemingly 'unfeminine' as the rise of women's literary professionalism (...) may actually have reinforced more restrictive notions of "femininity", (56).

Quizás el ejemplo más patente en el siglo XVIII del cambio a un tipo de novela didáctica en la que se combina el entretenimiento con un, al menos aparente, compromiso con la ideología dominante de la mujer, lo tenemos en la obra de Eliza Haywood. Después de publicar una serie de novelas de contenido erótico y escandaloso y de ser violentamente atacada por Pope en The Dunciad, Haywood comprendió que si quería seguir gozando del favor del público tenía que "regenerarse" y adaptarse a los nuevos criterios de moralidad e instrucción. En The History of Miss Betsy Thoughtless (1751) acepta la nueva máscara de la mujer escritora y se convierte en una autora didáctica y casta. La defensa que en 1785 hizo Clara Reeve de la figura de Haywood resulta muy reveladora: 
...she repented of her faults, and employed the latter part of her life in expiating the offences of the former (...) Mrs. Heywood had the singular good fortune to recover a lost reputation, and the yet greater honour to atone for her errors. - She devoted the remainder of her life and labours to the service of virtue (...) May her first writings be forgotten, and the last survive to do her honour! (cit. en Jones, 1991: 185-6)

La crítica de la época enfatiza en sus reseñas que el didactismo y la instrucción deben ser la base de los textos escritos por mujeres y alaban a aquellas autoras que con sus textos contribuyen al desarrollo moral de sus lectores o, con otras palabras, a la aceptación de las reglas de conducta establecidas. Así, en una reseña sobre Darnley Vale; or Emelia Fitzroy (1789), de Mrs Bonhote, se afirma que las "Lessons in virtue and morality (which) do the greatest honour to the writer's heart" (cit. en Turner: 53), mientras que los poemas de Elizabeth Carter son objeto de una gran apología por su valioso contenido moral:

It has often been remarked, with what degree of truth we will not pretend to determine, that the female muse is seldom altogether so chaste as could be wished, and that most of our ladywriters are rather deficient in point of morality. To the honour of Mrs. Carter it may be said, that there is scarce a line in this volume which does not breathe the purest sentiments, and tend in some measure to the advancement of religion and virtue, which is, in our opinion, their strongest recommendation (cit. en Jones, 1991: 176).

En un interesante artículo titulado "Fanny Burney and the courtesy books" Joyce Hemlow utiliza el término "courtesy books" para describir aquellas novelas que, como las de Fanny Burney, incorporan las enseñanzas morales de los manuales de conducta de la época y por tanto intentan crear una heroína perfecta ${ }^{8}$, que por supuesto, ha de mostrar las virtudes que se espera que una mujer posea en la vida real: obediencia, castidad, decoro, delicadeza, compasión y sentido del deber. Ha de abstenerse de mostrar sentimientos profundos hacia cualquier hombre que no sea su marido y huir de situaciones que puedan comprometer su tan preciada reputación. Rogers ha afirmado que es esta excelencia la que convierte a las heroínas del siglo XVIII en seres anodinos e irreales, mientras que Brownstein ha enfatizado el carácter ideal, imaginativo y temporal de estos seres perfectos en los que la pureza de alma y cuerpo se solapan:

An Exemplar is too good for the real goods of the real world. She is not born but made; she is not growing but fixed; she is not human but perfect. That an actual woman can be an Exemplar is, for all its Protestant trappings, a Romantic idea; a girl can no more remain an Exemplar than Keats could stay married to the nightingale. Like the poet's ecstasy, the Exemplar's existence is by definition temporary and ideal, an imaginative construct (43).

Yo creo, en contraposición con la mayoría de la crítica, que aunque Miss Milner se desvía en algunos casos del camino a seguir, en lo esencial se adapta al ideal de decoro de la

\footnotetext{
${ }^{8}$ En The Courtship Novel, 1740-1820 Katherine Sobba Green explica cómo, aunque estas autoras aceptaran e incorporaran a sus novelas las ideas de los manuales de conducta, al estar las primeras escritas por mujeres y los segundos en su mayoría por hombres, el mensaje final no puede ser el mismo en ambos casos, distinguiéndose en los textos de las novelistas posicionamientos claramente feministas.
} 
época y que fue este aspecto y no el hecho de que Inchbald hiciera pagar a Miss Milner por su comportamiento alegre y un tanto desafiante con el destierro y la muerte, lo que hizo que el siglo XVIII aceptara y celebrara las excelencias de una obra como A Simple Story.

Miss Milner es una muchacha de una gran belleza, que sorprende al lector por las contradicciones de su comportamiento y carácter. Al enviudar su padre, éste decide mandarla a un internado protestante ${ }^{9}$ en el que adquiere una educación más bien superficial y deficiente: "Her little heart employed in all the endless pursuits of personal accomplishments, had left her mind without one ornament, except those which nature gave, and even they were not wholly preserved from the ravages made by its rival, Art" (45). Por supuesto, Inchbald al referirse aquí a la mente de la protagonista no está aludiendo a su falta de preparación intelectual o académica, puesto que en líneas generales la educación de la mujer era muy limitada, sino al hecho de que Miss Milner desconoce cuál es el ideal de feminidad de la época y, por tanto, sus acciones y reacciones no se adaptan al mismo. Miss Milner es irreflexiva, impulsiva, imprudente, vehemente y directa en sus afirmaciones, vanidosa, acostumbrada a que todos los hombres se rindan a sus encantos y orgullosa de esa admiración que genera en el sexo masculino:

From her infancy she had been indulged in all her wishes to the extreme of folly, and habitually started at the unpleasant voice of control -she was beautiful, she had been too frequently told the high value of that beauty, and thought those moments passed in wasteful idleness during which she was not gaining some new conquest- she had besides a quick sensibility, which too frequently discovered itself in the immediate resentment of injury or neglect-she had acquired also the dangerous character of a wit; but to which she had no real pretensions, although the most discerning critic, hearing her converse, might fall into this mistake.- Her replies had all the effect of repartee, not because she possessed those qualities which can properly be called wit, but that what she said was spoken with an energy, an instantaneous and powerful perception of what she said, joined with a real or well-counterfeited simplicity, a quick turn of the eye, and an arch smile of the countenance (15).

Pero, a pesar de que Miss Milner no se adapta al perfil de la mujer modesta, sumisa, delicada, humilde, etc., sin embargo, posee otra serie de virtudes que cautivan la simpatía del lector, como son su generosidad, compasión por los que sufren, vivacidad e ingenuidad. Miss Milner se preocupa por el sobrino que Dorriforth mantiene, pero que no quiere ver porque su hermana se casó en contra de su voluntad, e incluso se atreve a llevarlo a casa de su tutor con la esperanza de que éste cambie de opinión, aunque sabe que ello puede provocar la ira de Dorriforth, como así sucede. Asimismo, ayuda a una mujer que le debe dinero a su padre, a Mr Milner, vendiendo sus joyas. El propio Dorriforth, que desaprueba el carácter frívolo de su pupila, es consciente de las virtudes que ésta posee:

Independent of her fortune, she has beauty to captivate the heart of any man; and with all her follies, she has a frankness in her manner, and unaffected wisdom in her thoughts, a vivacity in her conversation, and withal, a softness in her demeanour, that might alone engage the affections of a man of the nicest sentiments, and the strongest understanding (129).

\footnotetext{
${ }^{9}$ La madre de Miss Milner es protestante y su padre católico y al casarse deciden que los chicos serán educados en la fe del padre y las chicas en la de la madre.
}

Odisea, $n^{\circ} 5,2004$ 
Castle ha destacado que lo que redime a Miss Milner es su delicada sensibilidad y que su vivacidad es la que le da alegría a un escenario doméstico totalmente represivo. Esta afirmación de Castle queda patente en la relación que se establece entre Mr Sandford y la joven. Mr Sandford es un jesuita de ideas muy firmes y rígidas, antiguo preceptor de Dorriforth, cuya actitud ante una joven que no se adapta al ideal de mujer virtuosa es de total rechazo. Para él Miss Milner es una persona peligrosa de la que Dorriforth se debe librar lo antes posible dándola en matrimonio. Incluso llega a compararla con Lucifer, cuya belleza "was an aggravation of his guilt; because it shewed a double share of ingratitude to the Divine Creator of that beauty" (117). Para él es impensable que alguien como Dorriforth que ha renunciado a sus votos se case con una "coquette". El jesuita intenta humillar a Miss Milner y hacer que se avergüence de sí misma ignorándola y, aunque al principio parece conseguir su objetivo, la joven pronto sale de su letargo y se enfrenta abiertamente a su enemigo contestando sin tapujos a las alusiones que éste hace a su comportamiento. Incluso en alguna ocasión obedece a Dorrifoth sólo por el placer de atormentar a Sandford, que está siempre alerta para detectar sus fallos. Pero, a pesar de que el lector pueda entender la actitud de Sandford hacia una coqueta que disfruta con los halagos de su corte de admiradores, lo cierto es que los buenos sentimientos que la joven revela hacia Sandford a pesar de su enemistad, desarman al lector. Así, aunque Sandford no le guste, intenta reconciliarse con él y es precisamente el contraste entre la actitud cariñosa y compasiva de Miss Milner y la inflexibilidad de Sandford lo que contribuye de forma decisiva a crear una imagen más positiva de la joven. De este modo, por ejemplo, cuando Sandford acude a la casa de Dorriforth, que había prometido no pisar tras un enfrentamiento con su antiguo pupilo por culpa de Miss Milner, ésta deja de un lado su orgullo y rencor y recibe al jesuita con los brazos abiertos:

but going up to him with all the friendly benevolence which generally played about her heart, she took hold of one of his hands, and pressed it with a kindness which told him he was welcome more forcibly, than if she had made the most elaborate speech to convince him of it (67).

Por supuesto, Mr Sandford rechaza su calurosa bienvenida y su postura es importante porque revela que este hombre de firmes ideas carece de virtudes esenciales como son la caridad y la compasión que Miss Milner sí posee. De hecho, la narradora explica que aunque cuando están juntos Miss Milner y Mr Sandford discuten acaloradamente "but still in his absence, Miss Milner's good nature, and little malice, never suffered her to utter a sentence injurious to his interest.-Sandford's charity did not extend thus far;" (105). Incluso en algunas ocasiones Miss Milner llega a desarmar al viejo caballero, como cuando con sinceridad y verdadera preocupación le ofrece unas pastillas para el dolor de cabeza.

Pero Miss Milner no sólo se gana la simpatía del lector por su generosidad y compasión, sino porque en lo esencial se adapta a las normas de etiqueta y conducta de la época, tanto en su papel de hija, como de pupila y novia de Dorriforth. Miss Milner demuestra un profundo respeto y cariño por su padre y al morir éste acata sin el menor reproche sus instrucciones de irse a vivir a casa de Dorriforth. Aunque Dorriforth está un poco asustado 
por lo que ha oído contar sobre la conducta un tanto díscola y superficial de la "young woman of fashion" (6) que ha aceptado acoger bajo su protección, recibe una grata sorpresa cuando la joven se arrodilla ante él y, fiel a las reglas de juego, promete obedecerle como a un padre.

Pero en cuanto Miss Milner se adapta a su nueva vida en Londres, reanuda su desenfrenada vida social, haciéndose rodear de una corte de admiradores que no paran de agasajarla y adularla. Evidentemente, este comportamiento le preocupa a Dorriforth, consciente de que el más mínimo error - léase pérdida de su imagen de mujer casta y respetable - puede llevarla a la perdición y el rechazo social. De ahí que le inste a que lea más, se recluya en su casa y desarrolle aquellas virtudes que él y las normas establecidas consideran que una mujer debe poseer. La joven le escucha con atención e incluso a veces parece estar de acuerdo con su tutor, "but this, the first call of dissipation would change to illtimed raillery, or peevish remonstrance at being limited in delights her birth and fortune entitled her to enjoy" (18). Pero, aunque parezca que Miss Milner se rebela contra los criterios de su tutor, lo cierto es que cuando se trata de algún tema realmente importante y es consciente de que si no cumple lo ordenado despertará la ira de Dorriforth, no duda en adoptar una actitud sumisa. Así ocurre, por ejemplo, cuando Dorriforth sugiere que le diga a Lord Frederick, su más ferviente admirador, que deje de visitarla: "She smiled with ridicule at the caution, but finding it a second time repeated, and in a manner that savoured of authority, she promised to make, and to enforce the request" (20). Miss Milner sabe que Dorriforth no actúa de mala fe, sino que, como buen tutor, está profundamente preocupado por la relación de su protegida con un caballero de baja talla moral que puede manchar irremediablemente su honor. Además, la narradora insiste en la novela en que a pesar de sus diferencias de opinión, Miss Milner trata siempre a su protector con el máximo respeto:

With all that vast quantity of resentment, anger, or rage which sometimes boiled in the veins of Miss Milner, she was yet never wanting in that respect towards her guardian, which withheld her from uttering one angry sentence, immediately directed to him; and a severe word on his side, instead of exasperating, was sure to soften her (44).

Es cierto que en algunos casos, como explica Ty, Inchbald parece invertir las jerarquías establecidas y subvertir la autoridad patriarcal que Dorriforth simboliza, pero lo que esta estudiosa no describe es la cautela con que Inchbald lo hace para no herir la sensibilidad de sus lectores y dar la impresión de que está reafirmando el orden establecido. El primer ejemplo lo tenemos cuando Dorriforth, cansado de la desenfrenada vida social de su protegida, le prohíbe acudir a un evento. La reacción de Miss Milner no es de soberbia o enfrentamiento, sino que se echa a llorar y decide no contradecir a Dorriforth, puesto que cree que es su obligación: “'Do you think I would go,' answered Miss Milner, with an earnestness that for a time suppressed her tears, 'in contradiction to his will?'" (30). Cuando Dorriforth ve que acata su orden, le pide perdón por haberla tratado con tanta severidad y le permite ir a la fiesta. Si Inchbald, como dice Ty, estuviera aquí desestabilizando las jerarquías establecidas, la reacción inmediata de Miss Milner sería la de sentirse victoriosa por haber conseguido la sumisión de su protector. Sin embargo, su actitud es la que cabría esperar en una muchacha de la época, que se siente agradecida porque el poderoso ha sido 
condescendiente con ella: "Miss Milner, sunk underneath this kindness, and wept with a gentleness and patience, which did not give more surprise than it gave satisfaction to Dorriforth" (33).

Algo similar ocurre cuando Dorriforth ve a Frederick besándole la mano a Miss Milner y le propina una bofetada al seductor. Dorriforth se arrepiente de su comportamiento violento y poco honroso delante de una dama y le pide perdón de rodillas por lo que ha hecho:

She felt the indecorum of the posture he had condescended to take, and was shocked -to see her guardian at her feet, struck her with the same impropriety as if she had beheld a parent there; and all agitation and emotion, she implored him to rise, and with a thousand protestations declared, 'she thought the rashness of the act, was the highest proof of his regard for her' (62).

Para Ty el hecho de que la propia Miss Milner se dé cuenta de lo poco apropiado que es el comportamiento de Dorriforth es un claro indicio de que la joven ha conseguido subvertir las jerarquías existentes. Yo, por el contrario, creo que a través de la reacción de la joven y de su evidente consternación ante una situación que invierte los roles establecidos, Inchbald, al menos aparentemente, parece reafirmar el statu quo. Si la heroína hubiera mostrado satisfacción o alegría por lo ocurrido, la lectura, evidentemente, habría sido otra y habría provocado el rechazo de sus contemporáneos hacia una muchacha de ideas tan feministas. Además, Miss Milner no duda en disculparse cuando considera que ha cometido un error, como cuando trae al sobrino de Dorriforth a casa contra los deseos de su tutor. La propia Miss Milner en un momento dado confirma que, a pesar de que lleva una vida social que su protector desaprueba, en lo esencial se comporta como toda hija debe hacerlo, es decir, con sumisión y obediencia:

"Did I ever refuse, sir," returned she with a self-approving air, "to comply with any request you have seriously made me? Have I ever refused to obey your commands whenever you thought proper to lay them upon me? if not, you have no right to suppose I will now" (56).

Pero las cosas cambian cuando Miss Milner descubre que está enamorada de Dorriforth. Ty, Spencer y Castle han subrayado el carácter transgresor de las emociones de Miss Milner, que violan los códigos sociales, religiosos y culturales al subvertir algo tan sacrosanto como es la relación guardián/pupila e ignorar la ley de la Iglesia Católica, que impone el voto del celibato a sus religiosos. Si bien no cuestiono esta afirmación, sí considero importante resaltar la cautela con que Inchbald recrea los sentimientos de Miss Milner de manera que no escandalicen al lector. Es cierto que Miss Milner proclama abiertamente su pasión hacia Dorriforth: "I love him with all the passion of a mistress, and with all the tenderness of a wife." (72). Pero esta declaración de amor no sólo tiene lugar durante una conversación privada entre Miss Woodley y Miss Milner, sino que ésta admite que ha intentado con todas sus fuerzas controlar sus sentimientos hacia su protector, consciente de que hay algo ilícito en que una joven se enamore de su protector. La narradora intenta también justificar y defender a la protagonista argumentando que Miss Milner no se habría sentido tan atraída por su tutor si alguien le hubiera explicado con claridad las 
normas de la Iglesia Católica - recordemos que ha sido educada en la fe protestante - y que, aunque la heroína no puede borrar sus sentimientos e intenta en todo momento estar atractiva delante de Dorriforth, su propósito no es el de seducir a su guardián: "Could any supernatural power have endowed her with the means, and at the same time shewn to her the ills that must arise from such an effect of her charms, she had assuredly enough of virtue to have declined the conquest;" (81). De hecho, cuando Miss Woodley, escandalizada por lo que para ella es un auténtico sacrilegio, le dice a Miss Milner que han de alejarse una temporada de Londres para que olvide lo que siente hacia Dorriforth, la joven accede sin protestar. Además, hasta que no regresa de su "exilio" en Bath y se entera de que Dorriforth, ahora Lord Elmwood ha renunciado a sus votos, oculta sus emociones y no se hace ilusiones con respecto a su tutor, porque es consciente de lo reprobable de la situación. Es entonces cuando Miss Milner vuelve a confiarle a Miss Woodley que a quien quiere realmente es a Dorriforth y no, como todos creen, al lascivo de Frederick:

"What, love a rake, a man of professed gallantry? Impossible.-To me, a common rake is as odious, as a common prostitute is to a man of the nicest feelings.- Where can be the pride of inspiring a passion, fifty others can equally inspire? or the transport of bestowing favours, where the appetite is already cloyed by fruition of the self-same enjoyments?" (120).

Para Castle estamos ante una celebración de lo prohibido sin precedentes en la ficción inglesa, pero quizás, aunque eso sería tema para otro trabajo, lo que Inchbald está haciendo aquí es atacando la doble moralidad de la época que exige la mayor pureza de la futura mujer, mientras que es totalmente permisible con el comportamiento del hombre.

Una vez que Dorriforth confiesa su amor por Miss Milner las cosas cambian nuevamente y Miss Milner decide poner a prueba a su enamorado para ver hasta qué punto tiene poder sobre él:

"Why did I not keep him longer in suspense? he could not have loved me more, I believe; but my power over him might have been greater still.- I am the happiest of women in that affection he has proved to me, but I wonder whether it would exist under ill treatment? if it would not, he still does not love me as I wish to be loved-if it would, my triumph, my felicity, would be enhanced" (138).

Miss Milner hace todo lo que su amado desaprueba: malgasta el dinero, compra cosas que no necesita, sale hasta altas horas de la noche en compañía nada recomendable, etc. Miss Woodley le advierte que Lord Elmwood la está observando con gran atención para tomar una decisión sobre su futuro, pero ella dice que no le importa y que va a ir más allá en su desafío haciendo algo que un hombre prudente nunca perdonaría y que Lord Elmwood va a tener que pasar por alto por su incondicional amor hacia ella. La crítica ha subrayado esta actitud desafiante de Miss Milner, pero lo cierto es que, como vimos en páginas anteriores, lo que está haciendo la heroína es disfrutando de ese espejismo de poder del que las mujeres gozaban durante el periodo de noviazgo. Ella misma lo refleja con gran claridad cuando dice: "As my guardian, I certainly did obey him; and I could obey him as a husband; but as a lover, I will not." (154). 
Miss Milner encuentra pronto el modo de comprobar hasta qué punto ejerce su influencia sobre Lord Elmwood. La heroína recibe una invitación para un baile de máscaras y, aunque su amado le prohíbe terminantemente asistir, ella decide desobedecer su orden. Para Ty y Castle estamos ante uno de los momentos más álgidos de la primera parte, en el que Miss Milner lleva hasta el extremo su lucha de poder con Dorriforth. Según Ty, junto a la transgresión de lo prohibido está la ruptura con los códigos sexuales imperantes, ya que la heroína elige un traje que, como explica la narradora, "although it was the representative of the goddess of Chastity, yet from the buskins, and the petticoat made to festoon far above the ankle, if had, on the first glance, the appearance of a female much less virtuous" (155). Con la elección de este disfraz Miss Milner está demostrando su rechazo a los estereotipos femeninos existentes: no es ángel ni prostituta, ni Virgen María ni bruja seductora. Miss Milner parece encarnar a Eva y María al mismo tiempo: "Her evocation of both chastity and sexuality is indicative of the ambivalent and contradictory position in which women are placed, as their subjectivity is constituted by conflicting forces: the desire to be sexually pure, as well as the desire to allure" (93). Ty también señala que el disfraz elegido por Miss Milner confunde las nociones de género, puesto que los sirvientes de Lord Elmwood no se ponen de acuerdo sobre si la joven iba vestida de hombre o de mujer. Al moverse en la frontera de lo andrógino y sexualmente ambiguo Miss Milner parece querer destruir la distribución de roles que la sociedad establece para el hombre y la mujer.

Castle también subraya el carácter subversivo del baile de máscaras y señala que éste es, ante todo, un emblema, una imagen utópica de liberación. Mientras que en novelas anteriores la virtuosa heroína intenta evitar la zona prohibida, pero al final por determinadas circunstancias termina entrando en ella, en el caso de Miss Milner nos encontramos con una mujer que desafía las normas al desear participar activamente en un entretenimiento que su amado le ha prohibido. Para Castle el objetivo fundamental del baile de máscaras es poner al descubierto relaciones de poder, dominación y sumisión: "More than in any previous work it emerges as an explicitly symbolic domain, a ground of power over which masculine and feminine desire contend" (309). Mientras que para Dorriforth el baile es una zona vetada y el pretexto para ejercer su autoridad sobre Miss Milner, para ésta la fiesta simboliza su propia libertad y la reafirmación de su autonomía como mujer. El hecho de que el disfraz de Diana resulte ser a la vez sexualmente ambiguo y ambiguamente sexual viene dado por el hecho de que Miss Milner elige precisamente a la más andrógina y sexualmente esquiva de las deidades clásicas. Artemis/Diana, cazadora y amazona, protectora de las vírgenes y los animales salvajes, a la que se la ha solido asociar con el matriarcado de la antigüedad y los cultos a la diosa madre, era considerada en el siglo XVIII la encarnación perturbadora del poder femenino. Pero lo más importante para Castle es que Diana también simboliza la sexualidad femenina autónoma: "Diana is free of ordinary structures of sexual subordination, her erotic inaccessibility a form of mastery" (312). Castle considera que esta asociación de Diana con el celibato y el poder se hace patente en la escena posterior al baile de máscaras, puesto que cuando Miss Milner decide aceptar el duro destino que ella misma se ha labrado con su actitud desafiante, es decir, su separación de Lord Elmwood, lo que está haciendo es eligiendo la castidad de Diana por encima de la 
sumisión a otra voluntad: "She is reconciled to alienation - to moral and psychic invisibility - if only to preserve her liberty" (313). De este modo Inchbald pone de manifiesto la terrible encrucijada en la que se encuentran las mujeres del siglo XVIII, que han de elegir entre el amor de su prometido o la independencia femenina, ya que ambos aspectos son incompatibles. El baile de máscaras ha sido la gran prueba para Miss Milner, que ha optado por su libertad, aunque ello haga que su existencia sea mucho más difícil. Es cierto que al final Miss Milner se casa con Lord Elmwood, pero en ningún momento la heroína pide perdón por la transgresión cometida o le promete a su amado ser sumisa el resto de su vida: "Via the great intervening "proof" of the maquerade, she has challenged his authority - and won" (319).

Evidentemente hay algo de subversivo en el comportamiento de Miss Milner con respecto al baile de máscaras, pero lo que Ty y Castle no indican o analizan es el cuidado con que Inchbald relata todo el episodio y sus consecuencias para atenuar la gravedad de la infracción cometida por la heroína y así hacer posible que el lector acepte el matrimonio con el que termina la primera parte. En primer lugar, la noche en que va a tener lugar el baile de disfraces Lord Elmwood tiene planeado ir a Windsor para participar al día siguiente en una cacería, lo cual Miss Milner interpreta como una excusa "to give her an opportunity of passing the evening as she pleased, without his being obliged to know of it, and consequently to complain" (156). Es decir, Miss Milner no cree que esté realmente cometiendo una ofensa enorme al acudir a la fiesta, pues está convencida de que el propio Lord Elmwood no está tan enfadado con ella como aparenta y de que le está dejando el camino libre para que haga lo que quiera sin que se produzca un enfrentamiento entre ellos. Este aspecto es muy importante no sólo porque cualifica sustancialmente la rebeldía de la joven, sino porque pone de manifiesto su ignorancia del mundo. Es cierto que Lord Elmwood no le explica a Miss Milner la razón por la que no quiere que vaya al baile, pero yo no creo que sea, como dice Castle, porque goza imponiéndole su autoridad a su amada, sino porque para él los motivos son tan obvios, que no necesita ni mencionarlos. Los bailes de máscaras no estaban considerados en el siglo XVIII la mejor diversión para las muchachas castas y virtuosas y, de hecho, en la novela Mrs Horton dice que no deberían anunciarse en los periódicos este tipo de fiestas que "tempt young women to their ruin" (158). La "reconvertida" Eliza Haywood escribe en 1744 un artículo sobre una joven, Erminia, auténtica encarnación de la pureza y la inocencia, que ve cómo su vida se derrumba tras acudir a un baile de máscaras: “they were no sooner enter' d, than both were bewilder' $d$ amidst the promiscuous Assembly, - the strange Habits, - the Hurry, - the Confusion quite distracted their Attention" (cit. en Jones, 1991: 39). Aunque la joven acude al evento con su hermano, pronto se separan y Erminia se ve rodeada de personas de ambos sexos cuya forma de hablar le resulta totalmente insultante. Erminia es seducida contra su voluntad por un caballero sin escrúpulos, y, aunque su novio insiste en casarse con ella a pesar de lo ocurrido, la muchacha decide alejarse del mundo y recluirse para siempre en el campo. La moraleja de la historia no puede ser más diáfana:

It is no every Woman would have resented such an Injury in the same Manner with Erminia; and it must be confess'd, that her Notions of Honour and Virtue had somewhat superlatively delicate in them.- What a Loss then to the World to be depriv' $d$ of son amiable 
an Example, as she would have doubtless prov'd, of conjugal Truth, Tenderness, and a strict Observance to every Duty the Men so much desire to find in her they make a Partner for Life (cit. en Jones, 1991: 44).

Siendo ésta la visión que el siglo XVIII tenía de los bailes de máscaras, no es de extrañar que Lord Elmwood se preocupe enormemente cuando se cancela la cacería y al volver a casa anticipadamente se encuentra con que Miss Milner está en la fiesta. De hecho, cuando la joven regresa él está totalmente pálido y tembloroso, no sólo por su indignación por lo que ha hecho la joven, sino también, como dice la narradora, por la alegría de ver que la muchacha ha llegado sana y salva a casa, es decir, casta.

Pero más interesante que la actitud de Dorriforth al enterarse de que Miss Milner ha acudido a la fiesta es la reacción de Miss Milner tras volver de tan anhelado acto social. En lugar de encontrarse eufórica y victoriosa, se siente abatida y decepcionada:

that she was sure she should never desire to go to a masquerade again.- The crowd and bustle fatigued her-the freedom offended her delicacy-and though she perceived she was the first object of admiration in the place, yet there was one person still wanting to admire; and the remorse at having transgressed his injunctions for so trivial an entertainment, weighed upon her spirits, and added to its weariness (161).

Con estos pensamientos Miss Milner está comportándose como cualquier mujer virtuosa de la época lo haría. Por un lado, rechaza por obsceno e indecoroso el baile de máscaras y, por otro, siente muchísimo haber desobedecido a su amado por algo tan trivial. Miss Milner no está aquí encarnando en absoluto el espíritu de post-saturnalia, como dice Castle, sino comportándose con la sumisión y ejemplaridad deseables en una mujer del siglo XVIII. Si Miss Milner hubiera alardeado de lo bien que lo pasó con sus amigos y de lo que disfrutó desobedeciendo a Lord Elmwood, los lectores habrían rechazado a este personaje por desafiar frontalmente las normas de la época. Ella, sin embargo, lamenta profundamente lo que ha hecho y cuando se enfrenta a su enamorado le dice "with some marks of humility, 'I suppose, my lord, I have done wrong'" (163). Es cierto que al final de la conversación y tras comunicarle Lord Elmwood su decisión de romper la relación, Miss Milner se enfrenta a él y le dice que no le necesita; también es verdad que Miss Milner le confiesa a Miss Woodley que Lord Elmwood debe ser el primero en dar un paso adelante si quiere que se produzca la reconciliación, pero la realidad es que Miss Milner, que pone a prueba a su amado volviendo a su vida de antes y viéndose con personajes como Lord Frederick, espera en vano a que Lord Elmwood se doblegue ante ella. De hecho, es Miss Milner la que se adapta a sus deseos, pues cuando Lord Elmwood le envía una carta para comunicarle que va a partir hacia el extranjero en una semana y le pide que hasta su marcha se abstenga de insultarle con la presencia en su casa de Lord Frederick, ella acata sus deseos, aunque sólo sea para demostrarle que no es tan mala como él cree y que posee la suficiente fortaleza para decirle adiós sin demostrar el dolor que su partida le causa.

Al final y gracias a la intervención de Mr Sandford los amantes se reconcilian, pero sin que en ningún momento Lord Elmwood haya tenido que bajar la cabeza y humillarse ante Miss Milner, como ella hubiera deseado. Además, cuando Sandford dice que está seguro 
de que Miss Milner cambiará y se comportará como una esposa ejemplar, la joven no rebate el comentario del jesuita. Asimismo, el hecho de que, a pesar de las inconsistencias, fallos y violaciones del decoro que comete Miss Milner, Lord Elmwood se case con ella no es una victoria tan gloriosa como la mayoría de los críticos nos han querido hacer ver, puesto que, como hemos comprobado, a lo largo de la novela Inchbald ha logrado que los actos de rebeldía estén cubiertos de un manto de sumisión y respetabilidad que los hacen aceptables para el lector.

Al principio vimos cómo para algunos estudiosos el hecho de que Miss Milner cometa adulterio y tenga que pagar por ello es un intento por parte de Inchbald de suavizar el mensaje subversivo de la primera parte y demostrar cómo aquellas mujeres que se enfrentan a las normas terminan pagando por ello. Yo, por el contrario, creo que a través de este final trágico de Miss Milner lo que Inchbald está realmente demostrando es la imposibilidad de la mujer de ser feliz en un matrimonio marcado por la autoridad y tiranía del marido y cómo el ideal del "companionate marriage", es decir, del matrimonio basado en el respeto, el cariño y la amistad, que, al menos en teoría, fue ganando adeptos a lo largo del siglo XVIII era simplemente eso, una quimera. La propia Miss Woodley lo resume perfectamente cuando Miss Milner espera en vano que Lord Elmwood le muestre su sumisión tras su enfrentamiento y separación:

...He may love you too well to spoil you-consider, he is your guardian as well as your lover, he means also to become your husband; and he is a man of such nice honour, he will not give you a specimen of that power before marriage, which he does not intend to submit to hereafter (166).

\section{REFERENCIAS BIBLIOGRÁFICAS}

Armstrong, N. 1989. Desire and Domestic Fiction: A Political History of the Novel. New York: Oxford University Press.

BALlAStER, R. 2000. "Women and the rise of the novel: sexual prescripts". Women and Literature in Britain 1700-1800. 197-216.

Bradbrook, F. W. 1966. Jane Austen and Her Predecessors. Cambridge: Cambridge University Press.

Brophy, E. B. 1991. Women's Lives and the 18 ${ }^{\text {th }}$-Century English Novel. Tampa: University of South Florida Press.

BrownsteIn, R. M. 1994. Becoming a Heroine: Reading about Women in Novels. New York: Columbia University Press.

Castle, T. 1986. Masquerade and Civilization: The Carnivalesque in EighteenthCentury English Culture and Fiction. Stanford: Stanford University Press.

Doody, M. A. 1986. "Morality and annihilated time". Fetter'd or Free? British Women Novelists, 1670-1815. 324-358. 
Green, K. S. 1991. The Courtship Novel, 1740-1820: A Feminized Genre. Kentucky: University Press of Kentucky.

Hunt, L. C. 1986. “A woman's portion. Jane Austen and the female character”. Fetter'd or Free? British Women Novelists, 1670-1815. 8-28.

InCHBALD, E. 1998 (1791). A Simple Story. Ed. J.M.S. TomPKINS, with an introduction by Jane SPENCER. Oxford: Oxford University Press.

Jones, V., ed. 1991. Women in the Eighteenth Century: Constructions of Femininity. London \& New York: Routledge.

Cambridge University Press.

Kelly, G. 1976. The English Jacobin Novel, 1780-1805. Oxford: Clarendon Press.

LeGates, M. 1976. "The cult of womanhood in eighteenth-century thought". Eighteenth-Century Studies 10: 21-39.

Rogers, K. M. 1977. "Inhibitions on eighteenth-century women novelists: Elizabeth Inchbald and Charlotte Smith”. Eighteenth-Century Studies 11: 63-78.

Schofield, M. A. 1990. Masking and Unmasking the Female Mind: Disguising Romances in Feminine Fiction, 1713-1799. Newark: University of Delaware Press.

Schofield, M. A., \& C. MACHeski, eds. 1986. Fetter'd or Free? British Women Novelists, 1670-1815. Athens, Ohio and London: Ohio University Press.

SKINNER, G. 2000. "Women's status as legal and civic subjects: ‘A Worse Condition than Slavery Itself?”. Women and Literature in Britain 1700-1800. 91-110.

Spacks, P. M. 1994. Desire and Truth. Functions of Plot in Eighteenth-Century English Novels. Chicago \& London: University of Chicago Press.

Stone, L. 1990. The Family, Sex and Marriage in England 1500-1800. Harmondsworth: Penguin.

SutherLAND, K. 2000. "Writings on education and conduct: arguments for female improvement". Women and Literature in Britain 1700-1800. 25-45.

TodD, J. 1989. The Sign of Angellica: Women, Writing and Fiction, 1660-1800. New York: Columbia University Press.

TuRnER, C. 1992. Living by the Pen: Women Writers in the Eighteenth Century. London $\&$ New York: Routledge.

Ty, E. 1993. Unsex'd Revolutionaries: Five Women Novelists of the 1790s. Toronto: University of Toronto Press. 